\title{
A STUDY ON PROBLEM AND CHALLENGES OF WOMEN COIR WORKERS WITH SPECIAL REFERENCE TO ALAPPUZHA DISTRICTS
}

\author{
Megha Mahesh \\ Research Scholar, Department of Management Studies, Noorul Islam Centre for Higher Education, \\ Kanyakumari, Tamil Nadu
}

\begin{abstract}
Coir is a major traditional village business in India, which is centered on agrobased employment. India is the world's largest coir producer with over 80 percent of the world's total coir fiber production. Kerala is India's major coir and coir manufacturer. The coir industry has been developed in Kerala, and spreads to other coconut growing states of India. Coir industry is an export and employment industry. The study analysis the problems and challenges of women workers in household units of Alappuzha districts of Kerala. The study aims to know the family problem, employment related problem, financial problem, poor living condition of workers and identifying the problem and challenges faced by the women workers and provide them with suitable suggestions to overcome issues.
\end{abstract}

Keywords: Fiber, Household, Coir.

\section{INTRODUCTION}

India is the largest coir and coir product manufacturer and exporter. Currently, coir and its products are sold to over 80 countries, the US being the largest market with a share of more than $40 \%$ of overall exports. In the approaching years, coir geosynthesis and pith are anticipated to be the biggest item. Coir pith is environmentally beneficial. They are frequently used efficiently to enhance soil behavior, prevent soil erosion and promote soil consolidation. The production of coir products is an important cottage industry and considerably contributes to the economy of the main coconutmaking countries, like Kerala, Andhra Pradesh and Tamilnadu. In Kerala district, Alappuzha is one of the rural villages famous for coir products and coir units. Alappuzha is essentially a coconut and tourism-driven agricultural society. Because, coconut cultivation is very early on the major forming activity. More industries are solely in this village producing coir pith and fiber. Most of the coir units forms sickness and comes in closure of the firm and they moved to the another state like Tamil Nadu, Karnataka, AndraPradesh, Telugana, and West Bengal due to unavailability of raw materials and lack of skilled workers and labors. People have forgotten the values of traditional coir industry and going forward for the foreign product. By finding out the proper drawbacks from the problem of workers and industry point of view of both the factors which may lead to develop the coir industry as well as the workers personal life.

\section{OBJECTIVES OF THE STUDY}

1. To study the socio- economic condition of women coir workers in Alappuzha

2. To analysis the problem and challenges of women coir workers.

Hypothesis of the study

HO: There is no significant relationship between age and social economic condition of workers.

H1: There is a significant relationship between age and social economic condition of workers.

HO: There is no significant relationship between age and problem faced by women workers.

H1: There is a significant relationship between age and problem faced by women workers.

HO: There is no significant relationship between traditional worker and financial problem among women workers.

H1: There is a significant relationship between traditional worker and financial problem among women workers.

HO: There is no significant relationship between employed family members and problems of women workers 
H1: There is a significant relationship between employed family members and problems of women workers Hypothesis

\section{RESEARCH METHODOLOGY}

The study was carried out in Alappuzha district of Kerala is fully bloomed with coir industries. The study has covered the all areas of Alappuzha district. The primary data was collected in an interview schedule method. Secondary data was collected coir board journals, articles, coir magazines and questionnaire. The Study focuses only to women workers in house hold units. Sample size of the study is 175 calculated with Yamane method. Descriptive article sample design is used in the study. Simple random sampling method is used as sample design. The Percentage analysis and Anova is used has statistical tool in the present study.

\section{REVIEW OF LITERATURE}

* Lakshmi Devaraj (2021) the researchers focus on the personal financial problem of coir workers in private and public sector in Alappuzha district of Kerala. The study focus on the socio economic impact regarding the living condition include occupation, housing status, other income related aspects, low education level among the workers , poor financial capability of workers the researcher analysis the indebtedness and saving of workers which is very low and lack of financial literacy. The finding of the study deals with low level of saving and investment, comparison between the private and public sector workers personal financial aspect is low. The government must take a decision regarding the workers for their welfare and coir workers are the assets for coir units.

* M.S.Sasidharan (2018) the article deals with the passage of 5 years, the number of coir workers in the coir business has fallen to 50 per cent. According to him, the exploitation of the workmen is growing and the authorities in the coir sector are lacking sufficient attention. He added that most coir cooperatives don't operate and the operating companies can't provide employees with a minimum wage. He stressed the necessity for the healthy growth of the coir sector to ensure cooperation between the private and cooperative industry. The article calls for government aid to be extended to the private coir sector as well.

* Arjith Karun (2017) explains why coir yarn demand in the USA has plummeted. The United States is also seen as a big coir market. The study also shows that the Indian coir business is less competitive. One of the reasons for the drop in coir yarn intake is the lower area under Hop cultivation due to the usage of high yielding hybrid cultivars. The application of the conventional production process that was unable to withstand the Sri Lanka rivalry on the US market and shattered the Indian monopoly in terms of supplying hop coir yarn. The causes behind this are the emotive policies of coir sector in India against modernization and mechanization.

* Pandi (2015) stated that the problems of manufacturing, labour, sales, financing, and supervision were the reasons for the co-operative coir units' losses. He found the high production costs. The main reason for the high cost of production was due to the main issue of power and fuel supply.

\begin{abstract}
* Rajagopalan Nair(2013) The purpose of the study is to assess the performance of various cooperatives involved in the coir industry, to provide an overview of the industry, and to compare the performance of coir production units in the cooperative and private sectors. The researcher also highlights the industry's export rate. Even though it is an export industry, 75 to 85 percent of the output is exported to more than 100 countries. West European countries, East Asian countries, and African countries are the main buyers. The private sector continues to dominate the coir export market. There are over 140 exporters in the country. The industry manufactures 80 different yarn types, 174 different coir mats, 90 different coir mattings, and 80 different carpets. The average productivity of the coir fiber sector in Tamil Nadu is higher than the growth performance of the coir fully completed product sector in Kerala. As compared to Tamil Nadu, the researcher found that technological changes in Kerala's Coir Industry are very limited and low. It can be concluded that Kerala's Coir Industry's success and technological change are not insignificant when compared to Tamil Nadu.
\end{abstract}

* Nikhil Devdas (2013) the article was based on the coir industry has decided to move to Tamil nadu.With the fabled golden fibre that is interwoven with the lives of the four lakh coir workers in Alappuzha district, Kerala spread its name far and wide. The traditional industry, on the other hand, is in decline. With the scarcity of highquality coconut husk, the sector has become entirely reliant on coir units in Tamil Nadu's Pollachi for survival. The coir industry has been forced to relocate to Tamil Nadu due to labour shortages and high wages. According to industry leaders, the shift to coir geotextiles has resulted in a significant reduction in the supply of high-quality fibre. 
* Analeena (2016) the studies focus on the shifting of Kerala coir units to tamil nadu due to lack of demand in traditional product and unavailability of raw materials. The place of fabled glittering fiber, Alappuzha, has a red heart. Several labour uprisings in the Alappuzha district have left an indelible mark on Kerala's people's movement history. The district's social and economic status is determined by the sentiments of coir workers, farm laborers, and fishermen, who make up the majority of the people. However, the district is dealing with the economic consequences of the coir industry's relocation to Tamil nadu .

* Pylee (1975) conducted the research to analysis the issues that the coir industry faced in 1974. The key cause, according to the report, is a shortage of coir fiber, which is the industry's most essential necessity. The study also emphasized the need for this industry to be modernized by mechanization in order to boost export trends and lower increasing production costs. As per the report, in order to modernize the sector, priority should be given to the public sector and employees, and cooperatives should be formed to operate the husk beating machine. The study also placed a strong emphasis on research and development to improve new goods, as well as advertising to boost export and domestic sales.

\section{DATA ANALYSIS AND INTERPRETATION}

Table: 1

\begin{tabular}{|l|l|l|}
\hline AGE & FREQUENCY & PERCENTAGE \\
\hline Below 18 - 25 years & 2 & 1.14 \\
\hline Between 26 - 35 years & 5 & 2.85 \\
\hline Between 36 - 45 years & 65 & 37.14 \\
\hline Between 46 - 55 years & 92 & 52.57 \\
\hline Above 56 years & 11 & 6.28 \\
\hline TOTAL & 175 & 100 \\
\hline
\end{tabular}

The table shows the age of women workers in Alappuzha household coir units. 1.14 percentage of workers belongs to the age group of 18 to 25 years, 2.85 percentage of workers belongs to the age group of 26 to 35 years, 37.1 percentage of workers

Table: 2 belongs to the age group of 36 to 45 years, 52.5 percentage of workers belong to the age group of 46 to 55 years, $6.2 \%$ of workers belong to the age group of above 56 years.

\begin{tabular}{|l|l|l|}
\hline MARITAL STATUS & FREEQUENCY & PERCENTAGE \\
\hline SINGLE & 10 & 5.71 \\
\hline MARRIED & 160 & 91.42 \\
\hline WIDOWED & 2 & 1.14 \\
\hline DIVORCED & 3 & 1.71 \\
\hline
\end{tabular}


International Journal of Engineering Applied Sciences and Technology, 2021

Vol. 6, Issue 4, ISSN No. 2455-2143, Pages 302-310

Published Online August 2021 in IJEAST (http://www.ijeast.com)

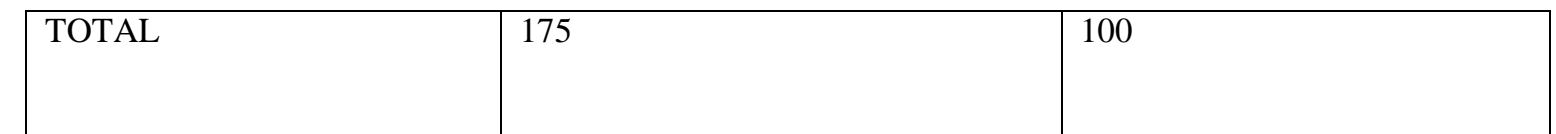

The table shows the marital status of women workers. $5.7 \%$ of women workers are single, 91.4 percentages of women workers are married and
1.14 percentages of women workers are widowed and 1.71 percentages of women workers are divorced in the Alappuzha districts

Table: 3

\begin{tabular}{|l|l|l|}
\hline EDUCATION & FREEQUENCY & PERCENTAGE \\
\hline ILLITERATE & 9 & 5.1 \\
\hline PRIMARY & 83 & 48 \\
\hline UPPER PRIMARY & 63 & 36 \\
\hline HIGH SCHOOL & & \\
\hline HIGHER SECONDARY & 16 & 9.1 \\
\hline TOTAL & 2 & 1.14 \\
\hline
\end{tabular}

The education status of the women workers in the Alappuzha district are $5.1 \%$ of workers are illiterate , $48 \%$ of the workers are primary level educated, 36 percentage of the workers are upper

Table: 4 primary educated, $9.1 \%$ of workers are high school educated, 1.14 percentage of workers are Higher Secondary educated.

\begin{tabular}{|l|l|l|}
\hline WORKER & FREEQUENCY & PERCENTAGE \\
\hline NEW ENTRANTS & 80 & 45.7 \\
\hline TRADITIONAL WORKERS & 95 & 54.2 \\
\hline TOTAL & 175 & 100 \\
\hline
\end{tabular}

In the above table explains that $4.2 \%$ of women workers are traditional workers and $45.2 \%$ of workers are not traditional workers they are new entrant workers.

Table: 5

\begin{tabular}{|l|l|l|}
\hline $\begin{array}{l}\text { MEMBERS EMPLOYED IN } \\
\text { THE FAMILY }\end{array}$ & FREEQUENY & PERCENTAGE \\
\hline
\end{tabular}


International Journal of Engineering Applied Sciences and Technology, 2021

Vol. 6, Issue 4, ISSN No. 2455-2143, Pages 302-310

Published Online August 2021 in IJEAST (http://www.ijeast.com)

\begin{tabular}{|l|l|l|}
\hline 1 & 125 & 71.4 \\
\hline 2 & 43 & 24.5 \\
\hline 3 & 7 & 4 \\
\hline 4 AND ABOVE & 0 & 0 \\
\hline TOTAL & 175 & 100 \\
\hline
\end{tabular}

The table shows that members employed in the family of workers $.71 .4 \%$ comes under one member employed in the family of women workers in the household coir per unit, $24.5 \%$ comes under two member employed in the family of women workers in the household coir per unit, $4 \%$ comes under three member employed in the family of women workers in the household coir per unit, no respondents comes under four and above member employed in the family of women workers in the household coir per unit

Table: 6

\begin{tabular}{|l|l|l|}
\hline EXPERIENCE & FREEQUENY & PERCENTAGE \\
\hline LESS THAN 7 YEARS & 2 & 1.14 \\
\hline $7-12$ YEARS & 20 & 11.42 \\
\hline $13-17$ YEARS & 14 & 8 \\
\hline $18-23$ YEARS & 24 & 13.7 \\
\hline $24-30$ YEARS & 40 & 22.8 \\
\hline ABOVE 31 YEARS & 75 & 41.4 \\
\hline TOTAL & 175 & 100 \\
\hline
\end{tabular}

The experience of the women coir workers are 1.14 percentage of workers experience is less than 7 years, 11.42 percentage of workers experience is 7 to 12 years, 8 percentage of women workers experiences is 13 to 17 years, 13.7 percentage of Table: 8 workers experience is 18 to 23 years, 22.8 percentage of women workers experience is 24.31, 41.4 percentage of workers experience is 31 years and above.

\begin{tabular}{|l|l|l|}
\hline SATISFIED WITH WAGES & FREEQUENCY & PERCENTAGE \\
\hline AGREE & 35 & 20 \\
\hline DISAGREE & 84 & 48 \\
\hline NEUTRAL & 30 & 19.14 \\
\hline STRONGLY AGREE & 6 & 3.4 \\
\hline STRONGLY DISAGREE & 15 & 8.57 \\
\hline
\end{tabular}


International Journal of Engineering Applied Sciences and Technology, 2021

Vol. 6, Issue 4, ISSN No. 2455-2143, Pages 302-310

Published Online August 2021 in IJEAST (http://www.ijeast.com)

TOTAL

175

100

The women coir workers in Alappuzha district satisfaction level of wages are $20 \%$ of workers agree with the wages, 48 percentage of workers disagree with the wages, $1.14 \%$ of workers neutral

Table: 9 satisfaction with the wages , $3.4 \%$ of workers strongly agree with the wages, $8.57 \%$ of worker strongly disagree with the wages.

\begin{tabular}{|l|l|l|}
\hline $\begin{array}{l}\text { PROBLEMS FACED BY } \\
\text { WORKERS }\end{array}$ & FREEQUENCY & PERCENTAGE \\
\hline DISAGREE & 45 & 25 \\
\hline AGREE & 75 & 42.8 \\
\hline NEUTRAL & 6 & 3.4 \\
\hline STRONGLY DISAGREE & 4 & 2.2 \\
\hline STRONGLY AGREE & 45 & 25 \\
\hline TOTAL & 175 & 100 \\
\hline
\end{tabular}

In the above table reveals that $25 \%$ of the women workers disagreed facing problem, $42.8 \%$ of women worker agreed facing problem, $3.4 \%$ of workers neutrally face problem, $2.2 \%$ of workers

Table: 10 strongly disagree with facing problem $25 \%$ of workers strongly agreed with facing problem in the coir sector regarding several reasons.

\begin{tabular}{|l|l|l|}
\hline $\begin{array}{l}\text { PROBLEMS OF WOMEN } \\
\text { WORKERS IN THE SECTOR }\end{array}$ & FREEQUENCY & PERCENTAGE \\
\hline Heavy load of work & 21 & 12 \\
\hline High expense for raw materials & 19 & 10.8 \\
\hline Inequality & 16 & 9 \\
\hline $\begin{array}{l}\text { Low level of wages } \\
\text { No a good relationship with Owners } \\
\text { and senior workers behavior }\end{array}$ & 19 & 14 \\
\hline $\begin{array}{l}\text { High stress level at work and health } \\
\text { related issues for workers }\end{array}$ & 11 & 10.8 \\
\hline $\begin{array}{l}\text { Improper balance between family } \\
\text { life and work life }\end{array}$ & 9 & 5.14 \\
\hline \begin{tabular}{l} 
Bad working condition \\
\hline
\end{tabular} & 10 & 6 \\
\hline
\end{tabular}


International Journal of Engineering Applied Sciences and Technology, 2021

Vol. 6, Issue 4, ISSN No. 2455-2143, Pages 302-310

Published Online August 2021 in IJEAST (http://www.ijeast.com)

\begin{tabular}{|l|l|l|}
\hline Long working hours in job & 17 & 9.7 \\
\hline Lack of job skill & 6 & 3.4 \\
\hline Personal financial problem & 22 & 12.5 \\
\hline TOTAL & 175 & 100 \\
\hline
\end{tabular}

The problem of women workers in the coir sector are $12 \%$ of workers response with heavy workload, $10.8 \%$ of workers response with high expenses for raw materials, $9 \%$ of workers response with inequality, $14 \%$ of workers response with low level of wages, $10.8 \%$ of workers response with not a good relationship with owners and senior workers behavior, $6 \%$ of workers response with high stress level at working place, $5.14 \%$ of workers response with improper balance between family life and work life, $5.7 \%$ of workers response with bad working quality, 9.7

Table: 11

ANOVA
$\%$ of workers response with long working hours in the job, $3.4 \%$ of workers response with lack of jobs skill in the coir sector, $12.5 \%$ of workers response with personal financial problems in the workers life.

\section{TESTING OF HYPOTHESIS}

HO: There is no significant relationship between age and social economic condition of workers.

H1: There is a significant relationship between age and social economic condition of workers.

\begin{tabular}{|l|l|l|l|l|l|}
\hline Source of variance & Sum of Squares & df & Mean Square & F & Sig. \\
\hline Between Groups & 1.488 & 1 & 1.488 & 7.495 & .007 \\
Within Groups & 69.072 & 173 & .198 & & \\
Total & 70.560 & 174 & & & \\
\hline
\end{tabular}

In the above table shows the result of ANOVA, it is recorded that the result of $\mathrm{P}$ value is .007

is less than 0.05 so the alternative hypothesis is accepted that is "There is a significant relationship between age and social economic condition of workers".
HO: There is no significant relationship between employed family members and problems of women workers

H1: There is a significant relationship between employed family members and problems of women workers

Table: 12

ANOVA

\begin{tabular}{|l|l|l|l|l|l|}
\hline Source of variance & Sum of Squares & df & Mean Square & F & Sig. \\
\hline Between Groups & 205.505 & 6 & 34.251 & 262.61 & .001 \\
Within Groups & 44.735 & 173 & .130 & 3 & \\
Total & 250.240 & 174 & & & \\
\hline
\end{tabular}


In the above table shows the result of ANOVA, it is recorded that the result of $\mathrm{P}$ value is .001 less than 0.05 so the alternative hypothesis is accepted that is "There is a significant relationship between employed family members and problems of women workers".
HO: There is no significant relationship between age and problem faced by women workers.

H1: There is a significant relationship between age and problem faced by women workers.

Table: 13

ANOVA

\begin{tabular}{|l|l|l|l|l|l|}
\hline Source of variance & Sum of Squares & df & Mean Square & F & Sig. \\
\hline Between Groups & 491.615 & 4 & 122.904 & 222.262 & .000 \\
Within Groups & 190.774 & 173 & .553 & & \\
Total & 682.389 & 174 & & & \\
\hline
\end{tabular}

In the above table shows the result of ANOVA, it is recorded that the result of $\mathrm{P}$ value is .000 less than 0.05 so the alternative hypothesis is accepted that is "There is a significant relationship between age and problem faced by women workers".
HO: There is no significant relationship between traditional worker and financial problem among women workers.

H1: There is a significant relationship between traditional worker and financial problem among women workers.

Table: 14

ANOVA

\begin{tabular}{|c|c|c|c|c|c|}
\hline Source of variance & Sum of Squares & df & Mean Square & $\mathrm{F}$ & Sig. \\
\hline Between Groups & 175.956 & 1 & 175.956 & 180.131 & .013 \\
\hline Within Groups & 339.933 & 173 & .977 & & \\
\hline Total & 515.889 & 174 & & & \\
\hline
\end{tabular}

In the above table shows the result of ANOVA, it is recorded that the result of $\mathrm{P}$ value is 0.13 which is less than 0.05 so the alternative hypothesis is accepted that is "There is a significant relationship between traditional worker and financial problem among women workers".

\section{FINDINGS}

- Majority of the women workers are belongs to the age group of 46 to 55 years in (52.5) coir sector.

- Majority of the women workers marital status is married (91.42\%) under household coir units in coir sector.
- Majority of the women workers education status is primary educated $(48 \%)$ are under High School level educated.

- Most of the women workers are traditional workers $(54.2 \%)$ they are unskilled workers, the workers do not to operate or run the machinery or new technologies.

- Most of the family members employed in the coir workers family are one member $(71 \%)$. The coir workers do not have any income from other sources.

- Majority of the coir workers are experience with more than 31 years (41.4). 
- Most of the women workers are disagreeing with the satisfaction level of wages (48\%).

- Majority of the women workers agreed (42.8) that faces problem in the coir sector due to lack of raw materials, poor government support, and financial problem for buying raw materials.

- The major problem of women workers is that low level of wages (14\%) and financial problem $(12.5 \%)$ in their personal life.

- Majority of the women worker response is that the socio- economic condition of the coir worker is very poor due to lack of education, weak financial performance, lack of training and development, poor skills.

- Majority of the coir worker face family related problem due to low level of wages, only one member in the family have income level in a month and improper balance between the family life and work life is due to long workers of work this is because of lack of technological adoption in the household coir units.

- Majority of the women workers face problems regarding health issues, inequality bad working condition lack of job skill heavy workload high level of stress etc. is proved in the study.

- Majority of the women workers face financial problem the life include low level of wages, lack of savings, children education, medical expenses, indebtedness, difficulty in getting loans, child rearing, unemployment due to natural calamity in the coastal region of Alappuzha and manmade calamities .

\section{SUGGESTION}

All women workers must be supplied with first aid facilities. Workers feel they are exploited by heavy labour, the employers must consider the reduction in employment. The study shows that even on key national and religious festival days, the coir workers are not provided holidays. The coir workers can declare national holidays as paid holidays. It is therefore proposed that the government may implement labour protection measures such as the provident fund and coir employees' medical facilities. In order to protect the welfare of coir industry workers, the Government can create a distinct department. The government must strive to raise salaries for employees in the coir industry. In the same way, equality of pay should be made by strongly endorsing regulations, for all types of untrained employment and systems of qualification for women. It has to be suggested that housing toilets, drinking water and any other minimum equipment should be provided at a workplace to safeguard the interest of female workers and efforts should be made to ensure adequate social security networks in the form of credit, medical and other benefits provision.

\section{CONCLUSION}

Since Coir is part of India's historic export and quality of coir manufactured in India is supporting quality, India has greater opportunity to expand its coir export abroad. Most exporters believe that coir promotion through generic marketing is crucial as sustainable natural fiber. At the end of international trade, economic development has played an extremely important role. It lets countries with the help of available domestic resources specialize in the production of certain commodities to serve the needs and desires of various parts of the world. The government of India has paid more attention to exports by providing various benefits and incentives with a view to increasing the possibility for employment, the inflow of exchanges, improve the standard of life and boost national and capital revenue.

\section{REFERENCE}

1 COIR BOARD Magazine VO1.13 (2021)

2 INDIAN - KAYAR VAVASAYA - RAJEEV PRASAD (2018)

3 www.visva-bharati.ac.in/.../Contents/cjmcreport-080413.pdf

4 http://en.wikipedia.org/wiki/Labour_in_India

5 ZoyaKhan/InCommentary/May28,2013http:ce ntreright.in/2013/05/women-in-unorganized sector/\#.Us hOyLSwab8

6 www.ccriindia.org/pdf/02History ofcoirindustry.pdf

7 http://www.the hindubusinessline.in/2004/02/18/stories/20040 21800421700.htm 